\title{
First Report of Biomarkers from Tabriz Lignite Beds (NW Iran)
}

\author{
Rana Shiri ${ }^{1}$, Aliasghar Siabeghodsy ${ }^{1, *}$, Reza Sabzi $^{2}$ \\ ${ }^{1}$ Department of Geology, Urmia University, Iran \\ ${ }^{2}$ Department of Chemistry, Urmia University, Iran
}

Copyright $(2016$ by authors, all rights reserved. Authors agree that this article remains permanently open access under the terms of the Creative Commons Attribution License 4.0 International License

\begin{abstract}
Biomarkers are very useful tools for paleontologists, especially where the undistinguishable organic matters like Tabriz lignite cannot be attributed to particular fossils. In this study, the important detected biomarkers in Tabriz lignite beds are Oleananes (Olean-12ene and Friedelane), beta carotene, Dibenzofuran and Gibberellic acid. The results indicate angiosperm higher and lower plants entering from adjacent areas into the lake sedimentary environment of the lignite beds. No biomarker of gymnosperm was found. The short chain even n-alkanes (C18 and C20) imply the contribution of marine microorganisms, C23 normal alkane is derived from terrestrial plants specially Sphagnum leaf wax, the existing simple methyl saturated alkanes (C11-C22) is derived from cyanobacteria and algae and thiophene formed by sulfate reducing bacteria. Thus, Tabriz lignite have two extrabasinal and intrabasinal origins that the first is made of the higher (angiosperms) and lower terrestrial plants have transported by runoffs into the basin and the second origin is made of seagrasses, cyanobacteria and algae within the lignite beds basin.
\end{abstract}

Keywords Biomarker, Cyanobacteria, Tabriz Lignite Beds

\section{Introduction}

Biological markers or biomarkers $[1,2]$ are molecular fossils, meaning that these compounds originated from formerly living organisms. Biomarkers are useful because their complex structures reveal more information about their origins than other compounds [3]. Coal and lignite beds are important geological, paleontological and geochemical samples that can provide essential information for terrestrial paleoenvironment and paleoclimate as well as paleobotany. Recently, biomarker investigation of coal and lignite have been performed, and contributed to the understanding of coal-forming paleoenvironment [4-9]. The characteristics of coal are influenced by many different factors, like vegetation type, climate, facies variation during peat accumulation and the extent of organic matter degradation during diagenesis. In the past, coal petrological and palaeobotanical data were the primary source of information about the coal forming environment and the ecology of peat formation. In more recent times, biomarker analysis of the soluble organic matter of coal has increasingly contributed to the understanding of the palaeoenvironment in the mires and has provided clues to the botanical input involved in their formation [10-15]. The organic matter content of lake sediments can be small or large, but its paleolimnological importance is always great. Its composition includes a variety of elemental, isotopic, and molecular indicators or proxies that can be used to reconstruct paleoenvironments of lakes and their surrounding land areas. The organic matter originates from the complex mixture of lipids, carbohydrates, proteins, and other biochemical components produced by the various organisms that have lived in and around the lake. As an accumulation of "geochemical fossils", the organic matter components in lake sediments provide information that can be used to reconstruct natural and human-induced changes in local and regional environmental systems [16]. In this paper, we study the biomarkers of Tabriz lignite beds and identify the organisms from which they originated.

\section{Materials and Methods}

\subsection{Geological Setting}

The Tabriz fault led to the formation of the Tabriz Basin in the Late Miocene [17]. The Neogene basin fill is composed from bottom to top of the Lignite Beds and the Fish Beds; the latter are overlain by Quaternary alluvial conglomerates [18]. Lignite and Fish Beds represent lake and swamp deposits with intercalations of volcanic ashes and tuffs. The Lignite Beds are up to $400 \mathrm{~m}$ thick and can be subdivided into a lower member, consisting of clay, mudstones, coarse-grained sandstones and conglomerates, and an upper member, comprising mudstones, fine-grained sand- stones, thin carbonate layers and lignite [19]. 


\subsection{Sample Collection}

The study area is under the influence of Tabriz fault. The studied section is the complete section in sampling time that has located at $38^{\circ} 03^{\prime} \mathrm{N}$ and $46^{\circ} 25^{\prime} \mathrm{E}$ coordinates. The lignite samples were collected from the upper member of the lignite beds at east of Tabriz city, on the heights of the SariDagh Mountains at Baghmisheh town (Fig. 1). The samples were collected in random. Each sample is about $40 \mathrm{gm}$. The geological map and the stratigraphic column of the studied section are shown respectively in Fig. 2 and Fig. 3.

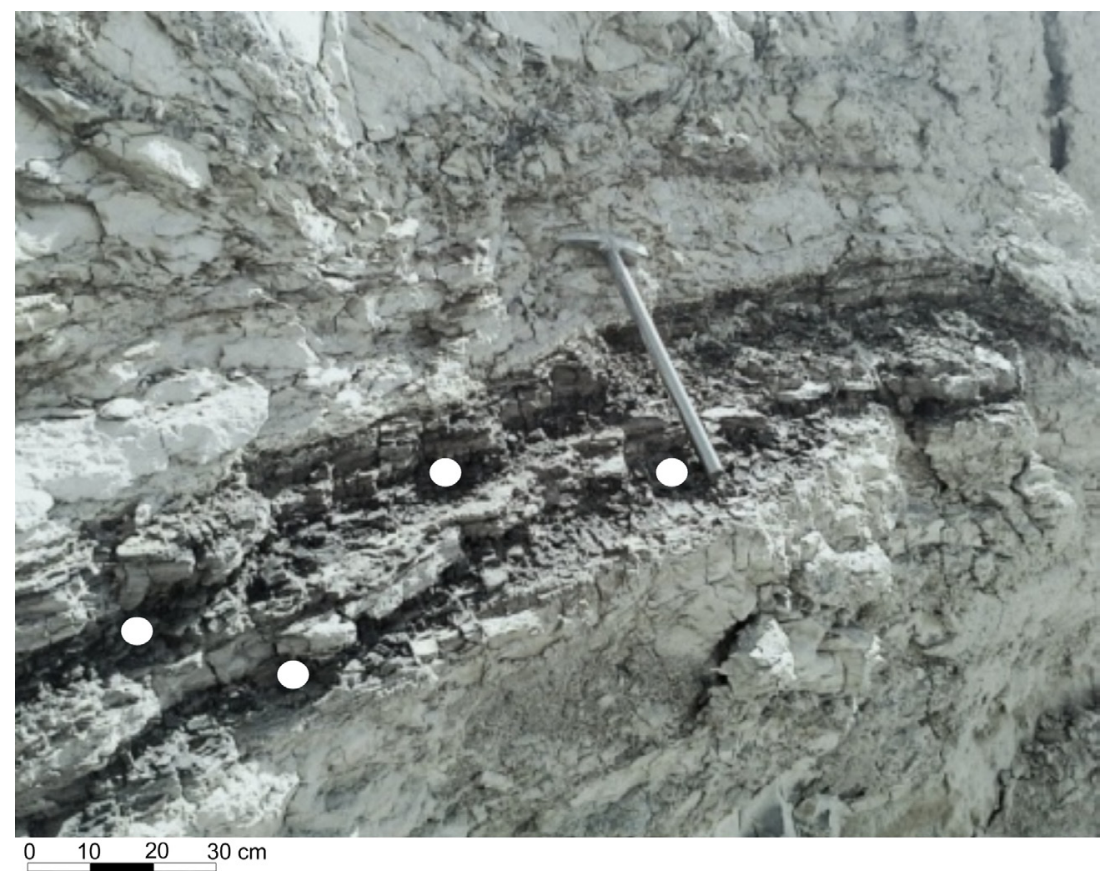

Figure 1. A part of Tabriz overturn Lignite beds on Sari- Dagh Mountains at Baghmisheh town. The white circles show some of random sampling positions.

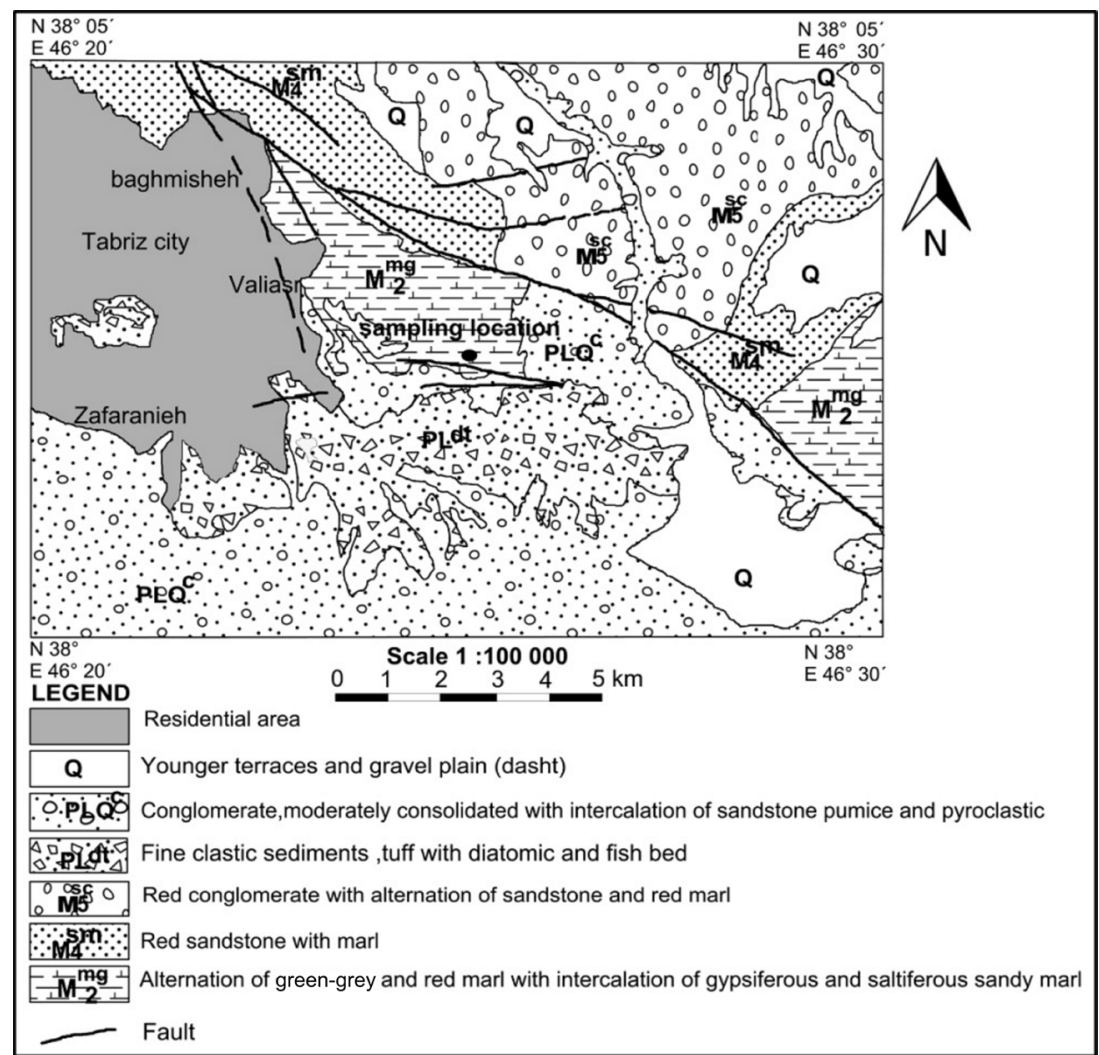

Figure 2. Geological map of the Tabriz Basin showing the location of the studied section on the lignite beds $\left(\mathrm{M}_{2}{ }^{\mathrm{mg}}\right)$ at Bagmisheh. Source: Geological map of Tabriz 1:100000 [20]. 


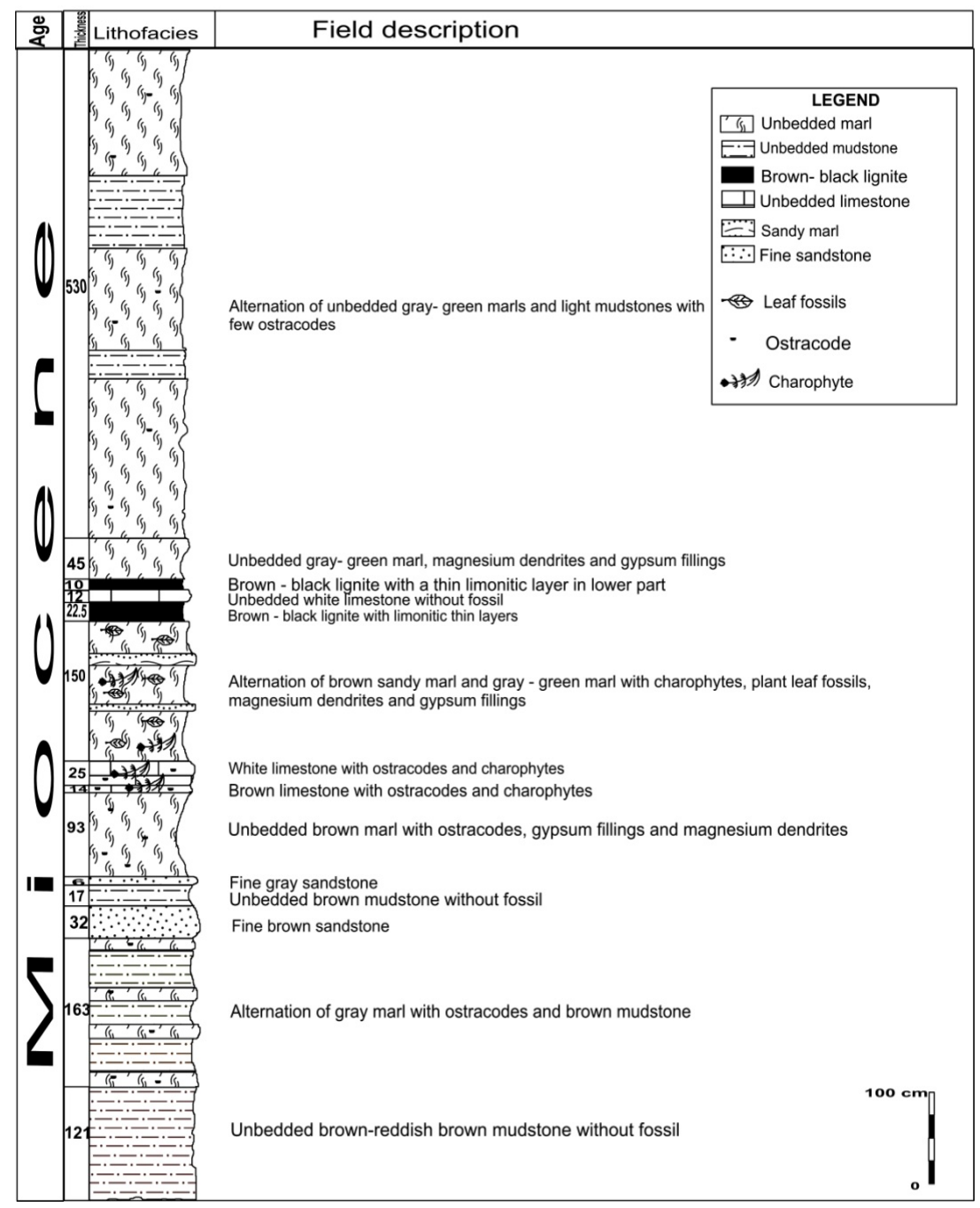

Figure 3. Stratigraphic column of the studied section on baghmisheh showing the lithofacies and the position of lignite beds.

\subsection{Lab Analysis}

Tabriz lignite beds are exposed at east of Tabriz city. Unfortunately, as for residential area development and excavations of Tabriz city toward east, the lignite beds were destructing and we tried to find more samples in a best a complete section. The experiments were performed on 24 handpicked lignite samples. The samples were crushed and powdered. We mixed them to obtain an average sample. The bitumen of $20 \mathrm{gm}$ of the average sample was extracted by Soxhlet apparatus (for $40 \mathrm{~h}$ ) with $500 \mathrm{ml}$ of benzene and ethanol (1:1) solvent. For asphaltene precipitation, the sample was dissolved in chloroform and the obtained solution was poured in cold hexane (ice bath). After making filtration, for chloroform evaporation, the oil fraction (maltenes) was concentrated by rotary evaporator. Obtained maltenes in this step $(0 / 107 \mathrm{gm})$, was dissolved in dichloromethane and was poured on a small amount of silica gel. The silica gel was leaved to dry the dichloromethane overnight. The sample covered the surface of the silica gel uniformly. This silica gel containing the sample was placed on top of a small column of silica gel and the fractions were eluted as follows: Fractions were eluted with n-hexane (aliphatics or saturates), $\mathrm{CH} 2 \mathrm{Cl} 2$ (unsaturates) and acetone (resins). Our biomarkers are saturated and unsaturated fractions that were detected by Gas chromatography- mass spectrometry. According to Stefanova [21], GC-MS analysis of the extracted fractions were performed on a Agilent6890n GC coupled to AgilentS973n quadrupole MS. Separation was achieved on a fused silica capillary column (HP $5 \mathrm{MS}, 0.25 \mathrm{~mm} \times 30 \mathrm{~mm} \times 0.25 \mu \mathrm{m}$ ). The $\mathrm{GC}$ operating conditions were as follows: temperature hold at $65^{\circ} \mathrm{C}$ for 2 min, increase from 65 to $300{ }^{\circ} \mathrm{C}$ at a rate of $6{ }^{\circ} \mathrm{C} / \mathrm{min}$ with final isothermal hold at $300{ }^{\circ} \mathrm{C}$ for $20 \mathrm{~min}$. Helium was used as the carrier gas. The sample was injected splitless with the injector temperature at $300{ }^{\circ} \mathrm{C}$. The mass spectrometer was operated in the electron impact mode (El) at $70 \mathrm{eV}$ ionization energy and scanned from 50 to 650 Dalton [21].

\section{Results}


In the studied section, the lignite beds are two layers with 10 and $22.5 \mathrm{~cm}$ thickness (Fig. 1 and 3). They are brownblack. There is a layer of unbedded white limestone with 12 $\mathrm{cm}$ thickness, without fossil between the lignite beds. In bottom of the lignite we have brown sandy and gray- green marls with charophytes, plant leaf fossils, magnesium dendrites and gypsum fillings. These lignite beds are overlain by unbedded gray- green marls with magnesium dendrites and gypsum fillings. Fig. 3 shows the stratigraphic column of the section on Baghmisheh area. Dominance of unbedded marls in bottom and top of lignite beds indicate fewer depths of sedimentary basin borders. Magnesium dendrites, gray- green marls and also the lignite beds indicate reduction conditions and the gypsum fillings imply the warm and dry climate. Thus, according to witnesses, the reduction and humid condition has been dominant. The sampling location has been specified at the east of Tabriz city on alternations of marls with intercalation of gypsiferous sandy marl with $\mathrm{M}_{2}{ }^{\mathrm{mg}}$ symbol on the geological map of Tabriz basin (Fig. 2). The TICs (Total ion current) of the biomarkers containing fractions are shown in Figs. 3 and 4. They show abundance vs retention time of biomarkers. Each of the peaks represents the signal of a compound and we paid attention to essential biomarker compound peaks. Fig. 4 shows the saturated fraction. The important biomarkers in this fraction are Cholestane, Friedelane (a saturated oleanane), some simple branched alkanes, medium chain length $\mathrm{C}_{23} \mathrm{n}$ - alkane and even $\mathrm{n}$ - alkanes $\left(\mathrm{C}_{18}\right.$, $\mathrm{C}_{24}$ ). Fig. 5 shows the unsaturated fraction and the essential biomarkers in this fraction are Beta carotene, Gibberellin acid, Oleane-12-ene (an unsaturated oleanane), Dibenzophurane, and Thiophene. We interpreted these peaks and recognized the organisms which they have originated from them (refer to discussion).

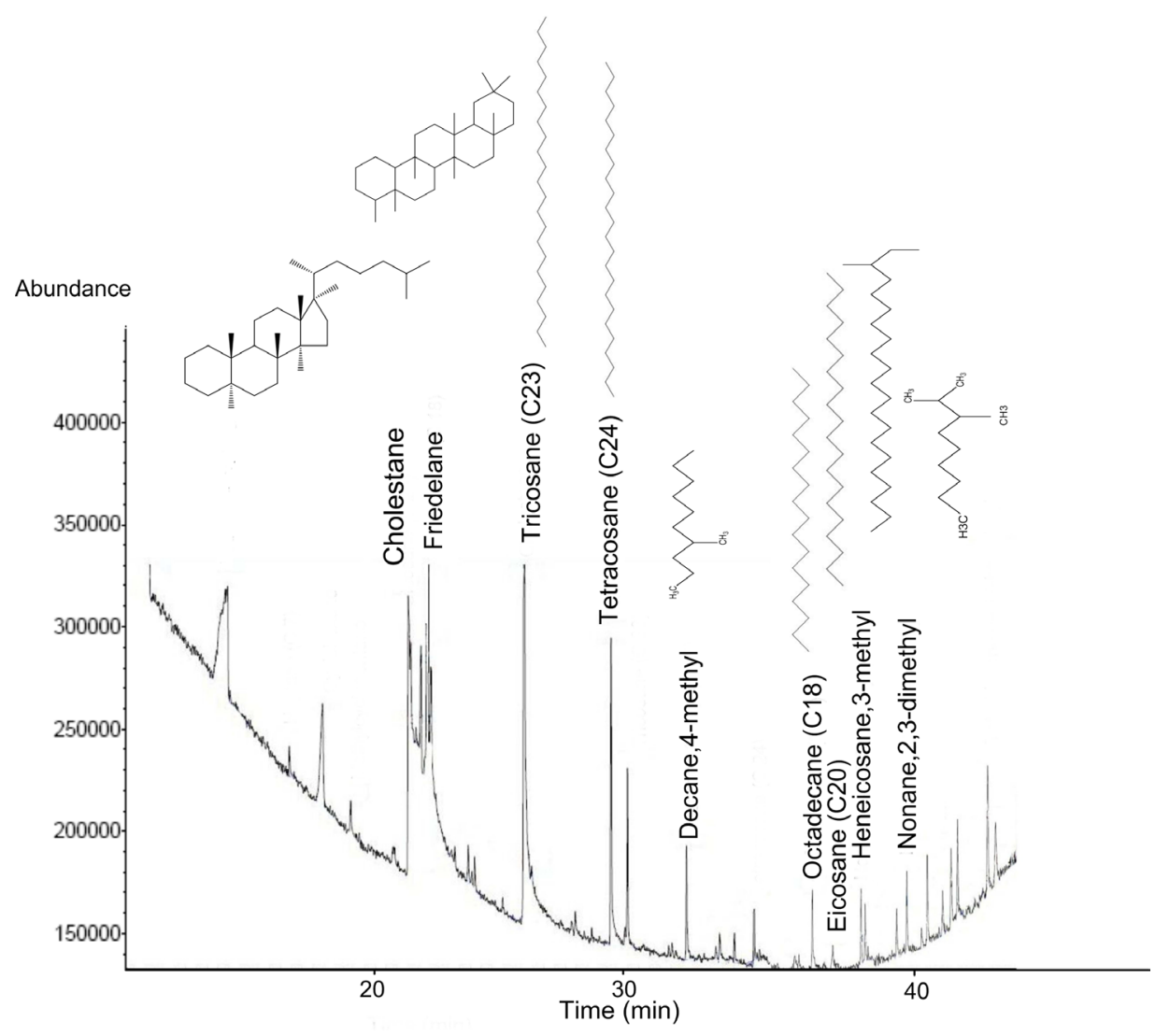

Figure 4. TIC (Total ion current) of the saturated fraction . 


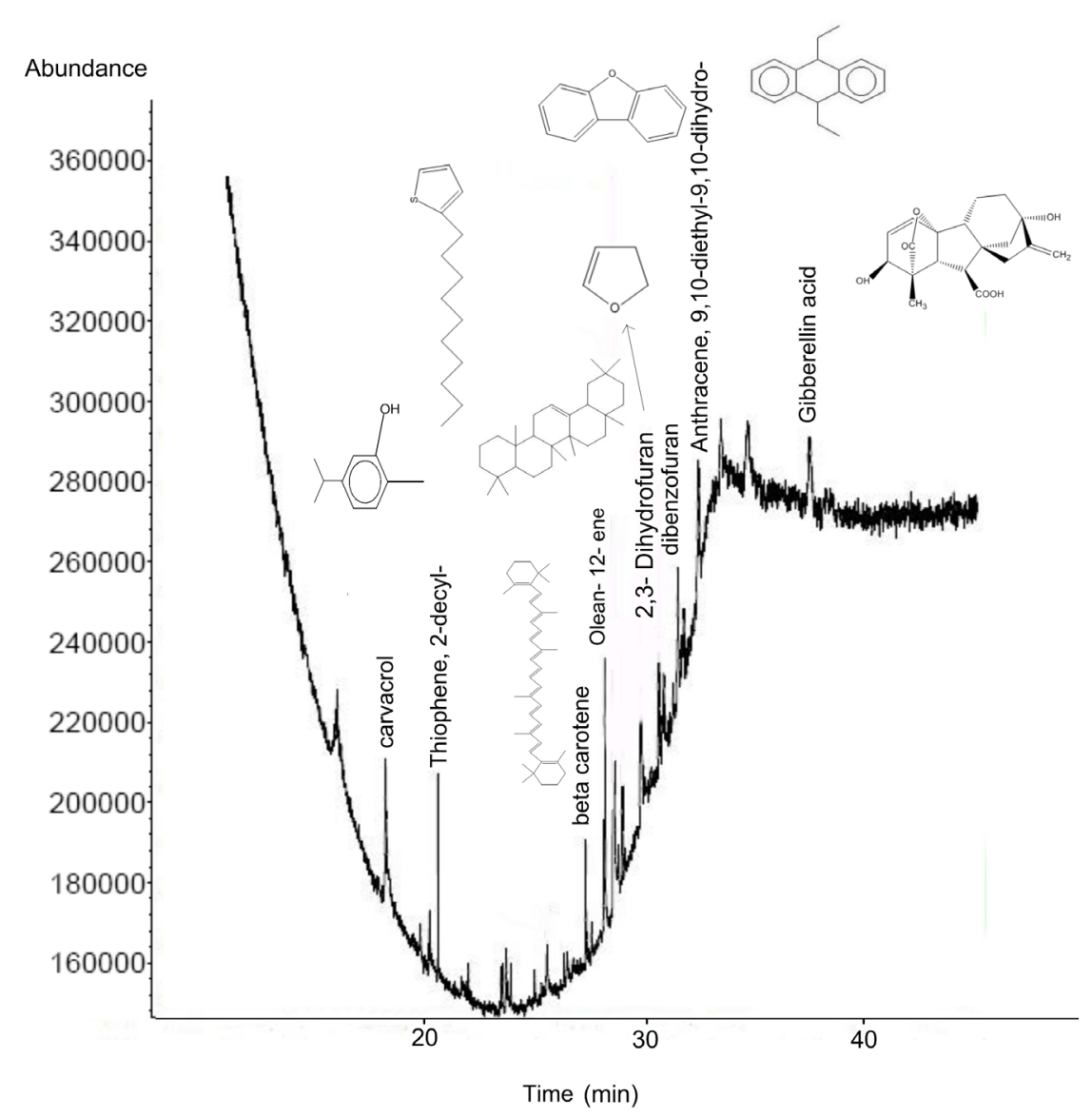

Figure 5. TIC (Total Ion Current) of the Unsaturated Fraction.

\section{Discussion}

Biological marker (biomarker) molecules are compounds that characterize certain biotic sources and retain their source information after burial in sediments, even after some alterations. Biomarkers in geologically old sediments and rocks are usually stabilized derivatives of their precursor compounds [16]. Here we have studied the saturated and unsaturated fractions for biomarkers.

\subsection{Saturated Fraction}

In saturated fraction (figure 4), we have the n-alkanes ranging from $\mathrm{C} 18$ to $\mathrm{C} 24$. The distribution of $\mathrm{n}$-alkanes demonstrated the predominance of even carbon n-alkanes $\mathrm{C} 18$ and $\mathrm{C} 20$ and $\mathrm{C} 24$. The predominance of these short chain even n- alkanes ( $\mathrm{C} 18$ and $\mathrm{C} 20$ ) indicates the contribution of marine microorganisms and petroleum products to the organic matter of sediments [23-25]. The C14 to $\mathrm{C} 20 \mathrm{n}$ - alkanes which are mostly derived from plankton and benthonic algae, are presumed to be abundantly available since Precambrian time [26]. Wiesenberg [27] showed that charring of grass biomass at 400 to $500^{\circ} \mathrm{C}$ produces exactly such $n$-alkane patterns. The long chain $\mathrm{C} 23$ odd carbon n-alkane was also present. This long chain odd carbon n-alkane is derived from terrestrial plants [28-32]. The dominance of C23 n-alkane has only been observed in
Sphagnum $[33,34]$, submerged/floating aquatic macrophytes [35], seagrass and associated sediments [36,37], Antarctic soils [38] and laminated carbonates from the Franconian Alb, SW-Germany [39]. Common rust fungus (Puccinia graminis f. sp. avenae) contained high abundant $\mathrm{n}-\mathrm{C} 23$ alkane in its airborne urediospores [40,41]. Also, Nichols [43] believe that sphagnum leaf wax is characterized by medium chain length $(\mathrm{C} 23-\mathrm{C} 25)$ n-alkanes $[33,42,43]$. Simple branched alkanes are found in many species of cyanobacteria [44] and in algal mats and lagoonal sediments [45]. Therefore, it can be concluded that Decane, 4- methyl, nonane, 2, 3- dimethyl and heneicosane, 4- methyl branched alkanes maybe are derived from cyanobacteria and algal mats. Cholestane $\left(\mathrm{C}_{27} \mathrm{H}_{48}\right)$ is a cyclic triterpeniod that represents in the saturated fraction. The dominance of cholestane may partly reflect the preservation of animal steroids [46]. Oleanane is a biomarker characteristic of angiosperms (flowering plants) found only in Tertiary and Upper Cretaceous rocks and oils [3]. Friedelane (a saturated oleanane) is a pentacyclic triterpene that is seen among the saturated biomarkers.

\subsection{Unsaturated Fraction}

Figur 5 has shown the unsaturated fraction. In this fraction we have these biomarkers: Carvacrol (2- methyl-5- (1methylethyl)- phenol) $\left(\mathrm{C}_{10} \mathrm{H}_{14} \mathrm{O}\right)$ is a predominant monoterpenic phenol which occurs in many essential oils of 
the Labiatae family including Origanum, Satureja, Thymbra, Thymus and Corydothymus species [47] that its frequency is significant. Oleane-12-ene is an unsaturated oleanane that as said it implies to presence of flowering plants and the tertiary age. Beta-carotene, $\mathrm{C}_{40} \mathrm{H}_{56}$, is one of several carotene isomers occurring in many lower and higher plants [26]. This tetraterpane presence is significant in this fraction. Also, many phases of plant growth and development are affected by the "gibberellins", which can be grouped among the cyclic diterpenoids. They occur, usually in small quantities, in all higher plants $[48,26]$. Gibberellic acid $\left(\mathrm{C}_{19} \mathrm{H}_{22} \mathrm{O}_{6}\right)$ is a gibberellin that is seen in the second fraction. Dibenzofuran (DBF), the derivatives of methyldibenzofurans (MDBFs) and dimethyldibenzofurans (DMDBFs) were identified as the oxygen-containing Compounds. In general, DBF is derived from the lower plants such as lichen and/or polysaccharide in terrestrial soil $[49,50,51]$. Thiophene is a sulphur- containing compound. Sedimentary organic sulfur compounds result from a reaction of reduced inorganic sulfur species, formed by sulfate reducing bacteria, and functionalized lipids during early diagenesis ("natural sulfurization) [45].

For the first time, Reichenbacher [19] have described the fossil fish and ostracod fauna and the diatom assemblages from both the Lignite Beds and Fish Beds. All fossil groups are characterized by the occurrence of freshwater and brackish forms; additional marine- euryhaline taxa appear among the fishes and diatoms. They believe the fossil assemblages indicate a new palaeogeography for the Late Miocene of the study area, with temporary connections between the Tabriz Basin and the southern Caspian Sea, perhaps via an ancient Araks River passage [19]. On the other hand, the $\mathrm{C} 11$ to $\mathrm{C} 23 \mathrm{n}$ - alkanes are obtained in the organic matter extracts from the Rhaghavapuram shales indicate marine inputs to the sedimentary organic matter [22]. Then it could be said that the marine biomarkers $(\mathrm{C} 18$ and $\mathrm{C} 20 \mathrm{n}$ - alkanes) among the Tabriz lignite lake biomarkers are probably because of marine inputs of the southern Caspian Sea to Tabriz sedimentary basin. Then, organic matters formed within the Tabriz Lake have marine and lake origins. Also, Tabriz lignite contains abundant terrigenous organic compounds such as dibenzofuran concentration and continental plant debris; we suppose that the large amount of terrigenous matters were transported to the Lignite beds basin by runoffs during the Lignite beds formation time. Therefore, Tabriz lignite has form from continental, marine and lake organisms.

\section{Conclusions}

In this study, the biomarkers of lignite are extracted from Tabriz Lignite Beds for the first time. The biomarkers in this formation such as cholestane, beta-carotene and oleananes indicate clastic material of angiosperm higher plants inputs into the basin and by ignoring gibberellic acid that exist in all high plants, there is no gymnosperm biomarker among these markers. In addition, the biomarkers such as normal and branched alkanes imply the presence of marine microorganisms (submerged /floating aquatic macrophytes, cyanobacteria and algae) and terrestrial plants at the formation time of this lignite. Therefore, lignite forming organic matters has two sources: extrabasinal and intrabasinal source. The extrabasinal source is debris of the high plants that were around the basin and the intrabasinal source is the seagrasses, cyanobacteria and algae that have lived within the basin during Miocene.

\section{Acknowledgements}

Sincerely thanks go to prof. Habil. Maya Stefanova from Bulgarian Academy of Sciences for laboratory protocol and valuable guides during this research.

\section{REFERENCES}

[1] G. Eglinton, P. M. Scott, T. Besky, A. L. Burlingame, M. Calvin. Hydrocarbons of biological origin from a one-billion-year-old sediment, Science, Vol.145, 263-4, 1964.

[2] G. Eglinton, M. Calvin. Chemical fossils. Scientific American, 216, 32-43, 1967.

[3] K. E. Peters, C. C. Walters, J. M. Moldowan. The biomarker guide. Biomarkers and Isotopes in the environment and human history. Cambridge university press, Vol.1, United Kingdom, 2005.

[4] P. G. Hatcher, D. J. Clifford. The organic geochemistry of coal: from plant materials to coal. Org. Geochem., Vol.27, 251-274, 1997

[5] M. M. Quirk, A. M. K. Wardroper, R. E. Wheatley, J. R. Maxwell. Extended hopanoids in peat environments. Chemical Geology, Vol.42, 25- 43, 1984.

[6] M. Ketola, E. Luomala, K. Pihlaja, T. Nyrönen. Composition of long chain fatty compounds and sterols of four milled peat samples from Finnish peat lands. Fuel, Vol.66, 600- 606, 1987

[7] A. Bechtel, R. F. Sachsen- hofer, I. Kolcon, R. Gratzer, A. Otto, W. Püttmann. Organic geochemistry of the lower Miocene Oberdorf Lignite (Styrian Basin, Austria); its relation to petrography, palynology and the palaeoenvironment, International Journal of Coal Geology, Vol.51, 31-57, 2002.

[8] M. Stefanova, B. R. T. Simoneit. Polar aromatic biomarkers of Miocene-aged Chukurovo resinite and correlation with a progenitor macrofossil, International Journal of Coal Geology. Vol.75, No.3, 166-174, 2008.

[9] K. Sawada, H. Nakamura, T. Arai, M. Tsukagoshi. Evaluation of paleoenvironment using terpenoid biomarkers in lignites and plant fossil from the Miocene Tokiguchi Porcelain Clay Formation at the Onada mine,Tajimi, central Japan. Elsevier Science, International Journal of Coal 
Geology. Vol.107, 78-89, 2013.

[10] W. Puttmann, M. Wolf, E. Wolff-Fischer. Chemical characteristics of liptinite macerals in humic and sapropelic coals. Org. Geochem. Vol.10, 625-632, 1985.

[11] J. Dehmer. Petrographical and organic geochemical investigation of the Oberpfalz brown coal deposit, West Germany, International Journal of Coal Geology, Vol.11, 273-290, 1989.

[12] J. Dehmer. Petrological and organic geochemical investigation of recent peats with known environments of deposition, International Journal of Coal Geology, Vol.28, $111-138,1995$.

[13] W. Kalkreuth, C. Keuser, M. Fowler, M. Li, D. Mcintyre, W. Puttmann, R. Richardson. The petrology, organic geochemistry and palynology of Tertiary age Eureka Sound Group coals, Arctic Canada, Org. Geochem., Vol.29, 799-809, 1998.

[14] A. Otto, V. Wilde. Sesqui-, di-, and triterpenoids as chemosystematic markers in extant conifers - a review, Botanical Review, Vol.67, 141-238, 2001.

[15] A. Bechtel, R. F. Sachsenhofer, A. Zdravkov, I. Kostova, R. Gratzer. Influence of floral assemblage, facies and diagenesis on petrography and organic geochemistry of the Eocene Bourgas coal and the Miocene Maritza- East lignite (Bulgaria), Elsevier, Org. Geochem., Vol.36, 1498-1522, 2005.

[16] P. A. Meyers. Application of organic geochemistry to paleolimnological reconstructions: a summary of examples from Laurentian Great Lakes, Org. Geochem., Vol.34, No.2, 261-289, 2003

[17] K. Kelts, M. Shahrabi. Holocene sedimentology of hypersaline Lake Urmia, Northwestern Iran, Palaeogeography, Palaeoclimatology, Palaeoecology, Vol.54, 105-130, 1986.

[18] H. Rieben. Contribution to the geology of the Persian Azerbeidjan, Bulletin of the Neuchâtel Society of Sciences, Naturelles, Vol.59, 19-144, 1935.

[19] B. Reichenbacher, H. Alimohammadian, J. Sabouri, E. Haghfarshi, M. Faridi, S. Abbasi, R. Matzke-Karasz, M. G. Fellin, G. Carnevale, W. Schiller, D. Vasilyan, S. Scharrer. Late Miocene stratigraphy, palaeoecology and palaeogeography of the Tabriz Basin (NW Iran, Eastern Paratethys), Elsevier, Palaeogeography, Palaeoclimatology, Palaeoecology journal, Vol.311, No.1-2, 1-18, 2011.

[20] O. Asadian. Geological map of Tabriz, Scale 1:100000, Geological Survey of Iran, 1993.

[21] M. Stefanova, D. R. Oros, A. Otto, B. R. T. Simoneit. Polar aromatic biomarkers in the Miocene, Maritza-East Lignite, Bulgaria, Elsevier Science, Org. Geochem., Vol.33, 1079-1091, 2002.

[22] S. Mukherjee. Petroleum Geosciences: Indian Contexts. Springer, U. S. A., 2015.

[23] J. Grimalt, J. Albaiges. Sources and occurrence of C12-C22 n-alkane distributions with even carbon number preference in sedimentary environments, Geochim. Cosmochim. Acta., Vol.51, 1379-1384, 1987.

[24] A. Garg, N. B. Bhosle. Abundance of macroalgal OM in biofilms: Evidence from n-alkane biomarkers, Biofouling, Vol.20, 155-165, 2004.

[25] R. R. Harji, A. Yvenat, N. B. Bhosle. Sources of hydrocarbons in sediments of the Mandovi estuary and the Marmugoa harbour, west coast of India, Environ. Int., Vol.34, 959-965, 2008.

[26] B. P Tissot, D. H. Welte. Petroleum formation and occurrence. 2th edition, Heidelberg: Springer Verlag, U. S. A., 1984.

[27] G. L. B Wiesenberg, E. Lehndorff, L. Schwark. Thermal degradation of rye and maize straw: lipid pattern changes as a function of temperature, Org. Geochem., Vol.40, No.2, 167-174, 2009.

[28] R. C. Jr. Clark, M. Blumer. Distribution of n-paraffins in marine organisms and sediment, Limnol, Oceanogr., Vol.12, 79-87, 1967.

[29] P. A. Cranwell. Chain length distribution of n-alkanes from lake sediments in relation to post glacial environment change, Freshwater Biol., 3, 259-265, 1973.

[30] A. Pearson, T. I. Eglington. The origins of n-alkanes in Santa Monica Basin surface sediment: A model based on compound-specific $\Delta 14 \mathrm{C}$ and $\delta 13 \mathrm{C}$ data, Org. Geochem., Vol.31, 1103-1116, 2000.

[31] O. O. Sonibare, O. S. Sojinu. Chemical composition of leaf lipids of angiosperms: Origin of land plant-derived hydrocarbons in sediments and fossil fuel, European J. Sci. Res., Vol.25, No.2, 192-199, 2009.

[32] V. R. Punyu, R. R. Harji, N. B. Bhosle, S. S. Sawant, K. Venkat. n-Alkanes in surficial sediments of Visakhapatnam harbour, east coast of India, J. Earth Syst. Sci., Vol.122, No.2, 467-477, 2013.

[33] C. J. Nott, S. Xie, L. A. Avsejs, D. Maddy, F. M. Chambers, R. P. Evershed. n-alkane distributions in ombrotrophic mires as indicators of vegetation change related to climatic variation, Org. Geochem., Vol.31, No.2-3, 231-235, 2000.

[34] X. Huang, C. Wang, J. Xue, P. A. Meyers, Z. Zhang, K. Tan, Z. Zhang, S. Xie. Occurrence of diploptene in moss species from the Dajiuhu peatland in southern China, Org. Geochem., Vol.41, No.3, 321-324, 2010.

[35] K. J. Ficken, B. Li, D. L. Swain, G. Eglinton. An n-alkane proxy for the sedimentary input of submerged/ floating freshwater aquatic macrophytes, Org. Geochem., Vol.31, No.7-8. 745-749, 2000.

[36] R. Mead, Y. Xu, J. Chong, R. Jaffé. Sediment and soil organic matter source assessment as revealed by the molecular distribution and carbon isotopic composition of n-alkanes, Org. Geochem., Vol.36, No.3, 363-370, 2005.

[37] Y. Xu, R. N. Mead, R. Jaffé. A molecular marker- based assessment of sedimentary organic matter sources and distributions in Florida Bay, Hydrobiologia, Vol.569, No.1, 179-192, 2006.

[38] G. I. Mat sumoto, E. Honda, K. Sonoda, S. Yamamoto, T. Takemura. Geochemical features and sources of hydrocarbons and fatty acids in soils from the McMurdo Dry Valleys in the Antarctic, Polar Sci., Vol.4, No.2, 187-196, 2010.

[39] L. Schwark, M. Vliex, P. Schaeffer. Geochemical 
characterization of Malm Zeta laminated carbonates from the Franconian Alb, SWGermany (II), Org. Geochem. Vol.29, No.8, 1921-1952, 1998.

[40] J. L. Laseter, R. Valle. Organics associated with outer surface of airborne urediospores, Environ Sci., Technol., Vol.5, No.7, 631-634, 1971.

[41] X. Huang, J. Xue, Sh. Guo. Long chain n- alkanes and their carbon isotopes in lichen species from western Hubei Province: implication for geological records, Earth science, Vol.6, No.1, 95-100, 2012.

[42] R. D. Pancost, M. Baas, B. van Geel, J. S. Sinninghe Damste'. Biomarkers as proxies for plant inputs to peats: an example from a sub-boreal ombrotrophic bog, Org. Geochem., Vol.33, 675-690, 2002.

[43] J. E. Nichols, R. K. Booth, S. T. Jackson, E. G. Pendall, Y. Huang. Paleohydrologic reconstruction based on n-alkane distributions in ombrotrophic peat, Org. Geochem., Vol.37, 1505-1513, 2006.

[44] A. O. Barakat, M. Kim, Y. Qian, T. L. Wade. Organochlorine pesticides and PCBs residues in sediments of Alexandria Harbour, Egypt, Mar. Pollut. Bull., Vol.44, 1421-1434, 2002.

[45] J. K. Volkman. Marine Organic Matter: Biomarkers, Isotopes and DNA, The Handbook of Environmental Chemistry, Vol.2, Springer, U. S. A., 2006.
[46] P. A. Hall, D. M. McKirdy, G. P. Halverson, J. B. Jago, J. G. Gehling. Biomarker and isotopic signatures of an early Cambrian Lagerstätte in the Stansbury Basin, South Australia, Org. Geochem., Vol.42, 1324-1330, 2011.

[47] B. Aristatile, A. H. Al assaf. Carvacrol ameliorates the PPAR- $\alpha$ and cytochrome P450 expression on Dgalactosamine induced hepatotoxicity rats, 5th International Conference on Biomarkers and Clinical Research, St. Hilda's College, University of Oxford, UK. Vol.11, No.3, 118-123, April 15-17, 2014.

[48] J. Macmillan. Diterpenes- the gibberellins. In: Goodwin, T. W. ed. Aspects of Terpenoid chemistry and biochemistry, Academic press, London, 153-180, 1971.

[49] M. Radke, S. P. Vriend, L. R. Ramanampisoa. Alkyldibenzofurans in terrestrial rocks: Influence of organic facies and maturation, Geochim. Cosmochim. Acta., Vol. 64, No.2, 275-286, 2000.

[50] M. A. Sephton, C. V. Looy, H. Brinkhuis, P. B. Wignall, J. W. de Leeuw, H. Visscher. Catastrophic soil erosion during the end-Permian biotic crisis, Geology, Vol.33, 941-944, 2005.

[51] K. Okano, K. Sawada, R. Takashima, H. Nishi, H. Okada. Depositional Environments Revealed From Biomarkers in Sediments Deposited During the Mid-Cretaceous Oceanic Anoxic Events (OAEs) in the Vocontian Basin (SE France), International Symposium of "The Origin and Evolution of Natural Diversity”, Sapporo, 233-238, 1-5 October, 2007. 